Check for updates

Cite this: RSC Adv., 2018, 8, 14603

Received 2nd February 2018

Accepted 28th March 2018

DOI: $10.1039 / c 8 r a 01037 d$

rsc.li/rsc-advances

\section{A methylene blue-based near-infrared fluorescent probe for rapid detection of hypochlorite in tap water and living cells $\uparrow$}

\author{
Xin Huang, ${ }^{a}$ Zhipeng Li, ${ }^{a}$ Tingting Cao, ${ }^{a}$ Qian Cai, ${ }^{a}$ Chengchu Zeng, ${ }^{a}$ Hua Fu (D) ${ }^{b}$ \\ and Liming $\mathrm{Hu}$ (iD *ab
}

A methylene blue-based near-infrared fluorescent probe was designed for the selective determination of hypochlorite $\left(\mathrm{ClO}^{-}\right)$, over other reactive oxygen species or interfering agents. Acetylated methylene blue was synthesized by introducing the acetyl group into the methylene blue framework, which can specifically recognize exogenous and endogenous $\mathrm{ClO}^{-}$. The acetylated methylene blue fluorescent probe was characterized by ${ }^{1} \mathrm{H}$ NMR, ${ }^{13} \mathrm{C} \mathrm{NMR}$ and HRMS. The response process and possible mechanism were studied using products of the probe. The emission response of the probe to $\mathrm{ClO}^{-}$ presented good linear relationship in the 0-60 $\mu \mathrm{M}$ concentration range, with the detection limit of 0.1 $\mu \mathrm{M}$ (measured at $660 \mathrm{~nm}$ and $690 \mathrm{~nm}$ ). The absorption and emission wavelengths of acetylated methylene blue are both in the near-infrared region; in addition, the probe itself and the degradation products were well-dissolved in water and have almost no toxicity. The probe was used for intracellular $\mathrm{ClO}^{-}$imaging and showed a large fluorescence enhancement (about 200 -fold increase).

\section{Introduction}

Hypochlorite $\left(\mathrm{ClO}^{-}\right)$is widely used as a disinfectant and bleaching agent daily, and it is one of the biologically important reactive oxygen species (ROS). ${ }^{1}$ ROS play important roles in the human immune defense system and the destruction of invading bacteria and pathogens..$^{2-4}$

In living organisms, $\mathrm{ClO}^{-}$is generated from hydrogen peroxide and chloride ion in activated neutrophils, catalyzed by myeloperoxidase (MPO). ${ }^{\mathbf{1 , 5 , 6}} \mathrm{ClO}^{-}$is commonly used in disinfectants and bleaches. ${ }^{7,8}$ However, excessive formation of hypochlorite can also cause tissue damage and a series of human diseases, such as atherosclerosis, arthritis and even cancers, etc. ${ }^{\mathbf{9}, 10}$ Therefore, the rapid and sensitive detection of $\mathrm{ClO}^{-}$is important in biological samples.

So far, many methods have been reported to detect $\mathrm{ClO}^{-}$, such as electrical analysis, potentiometric analysis, chemiluminescence, etc. ${ }^{11}$ Among them, the fluorescence method has the advantage of better sensitivity and selectivity. ${ }^{12-14}$ Fluorescent molecular probes can be employed as a powerful tool to track biomolecules in living systems due to their high

${ }^{a}$ College of Life Science and Bioengineering, Beijing Key Laboratory of Environmental and Oncology, Beijing University of Technology, Beijing, 100124, China. E-mail: huliming@bjut.edu.cn; Fax: +861067392001; Tel: +861067396211

${ }^{b}$ Key Laboratory of Bioorganic Phosphorus Chemistry and Chemical Biology (Ministry of Education), Tsinghua University, Beijing, 100084, China

$\dagger$ Electronic supplementary information (ESI) available. See DOI: 10.1039/c8ra01037d sensitivity, real-time assay and non-invasive monitoring capability. In addition, the small-molecule fluorescent probe has many characteristics. The most attractive points are its low cost and low toxicity. Herein, a reactive fluorescent probe responsive toward ROS is designed.

Methylene blue (MB) is a photosensitizer approved by the FDA. This oxidized phenothiazine compound is widely used in clinical and basic research. ${ }^{15}$ Recently, $\mathbf{M B}$ was also applied as a NIR (near-infrared) imaging agent in image-guided surgery. ${ }^{\mathbf{1 6}}$ As an ideal fluorescent group, the compound shows excellent photophysical properties, such as absorption and emission wavelength both in the NIR (more suitable for animal experiments to exclude background interference), almost no toxicity, and so on. So far, many new fluorescent probes have been reported based on near-infrared fluorophores. ${ }^{17-23}$

Here, we developed a highly sensitive and selective hypochlorite turn-on sensor (MBAC, Scheme 1). The probe was synthesized by acetylation of methylene blue and characterized by ${ }^{1} \mathrm{H}$ NMR, ${ }^{13} \mathrm{C}$ NMR and HRMS. Upon reaction with $\mathrm{ClO}^{-}$, the acetyl group leaves mbac, thus altering the fluorescent properties of the probe and achieving the detection of $\mathrm{ClO}^{-}$. Thus, MBAC is almost non-fluorescent; however, strong near-infrared fluorescence was detected from the $\mathrm{ClO}^{-}$response product. The advantage of mbac is that the emission wavelength is in the near-infrared region; especially, the fluorescence enhancement factor is large. The concentration is linearly related to the fluorescence intensity, and the detection limit is low.

We hypothesize that $\mathbf{m b a c}$ amide bonds are cleaved by $\mathrm{ClO}^{-}$, resulting in the release of fluorescent group $\mathbf{M B}$, while 

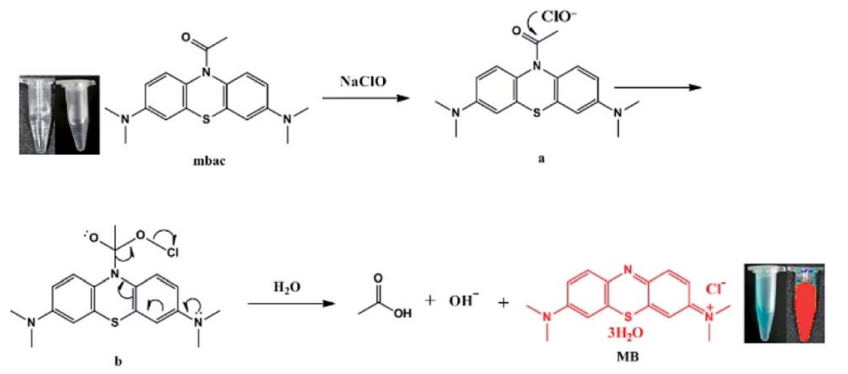

Scheme 1 Possible mechanism: the cleavage of the amide bond of the fluorescent probe mbac results from interacting with $\mathrm{ClO}^{-}$. (The left side of the illustration is the view of the naked eye, and the right side is the view under the Pearl® Impulse Small Animal Imaging System).

producing visible color changes and NIR emission (Scheme 1). This was verified by high-performance liquid chromatography (HPLC, Fig. 5). On the other hand, the experimental data show that MBAC was successfully utilized to detect endogenous hypochlorite in living cells, with excellent selectivity and sensitivity (the detection limit of $0.1 \mu \mathrm{M}$ ). According to its low cytotoxicity and high selectivity to $\mathrm{ClO}^{-}$, we see its application prospects and perform a series of tests on the probe.

\section{Experimental}

\section{Materials}

All reagents were purchased from commercial sources and used without further purification. MB and acetyl chloride were purchased from J\&K Scientific Ltd. (Shanghai, China). Solutions of various testing species were respectively prepared from $\mathrm{KCl}$, $\mathrm{NaCl}, \mathrm{LiCl}, \mathrm{MgCl}_{2}, \mathrm{HgCl}_{2}, \mathrm{Cs}_{2} \mathrm{CO}_{3}, \mathrm{AgNO}_{3}, \mathrm{FeCl}_{2}, \mathrm{FeCl}_{3}, \mathrm{CaCl}_{2}$, $\mathrm{ZnCl}_{2}, \mathrm{CuCl}_{2}, \mathrm{CH}_{3} \mathrm{COONa}, \mathrm{NaBr}, \mathrm{NaI}, \mathrm{Na}_{3} \mathrm{PO}_{4}, \mathrm{Na}_{2} \mathrm{HPO}_{4}$, $\mathrm{NaH}_{2} \mathrm{PO}_{4}, \mathrm{NaNO}_{2}, \mathrm{KMnO}_{4}, \mathrm{NaHCO}_{3}, \mathrm{NaF}, \mathrm{Na}_{2} \mathrm{~S}_{2} \mathrm{O}_{4}, \mathrm{GSH}$ and $\mathrm{NaClO}$. All solvents used in spectroscopic tests were spectroscopic grade. The water used in the experiments was deionized water.

\section{Methods}

General procedure for synthesis of 1-[3,7bis(dimethylamino)phenothiazin-10-yl]ethanone (mbac). All syntheses were carried out at atmospheric pressure using magnetic agitation and with thin-layer chromatography (TLC) monitoring. $\mathrm{MB}$ (0.5 mmol, $187 \mathrm{mg}), 1 \mathrm{~mL}$ water and $1.5 \mathrm{~mL}$ dichloromethane were mixed and stirred at $40{ }^{\circ} \mathrm{C}$ for 5 minutes. Then, sodium dithionite ( $1 \mathrm{mmol}, 175 \mathrm{mg}$ ) and sodium bicarbonate ( $1 \mathrm{mmol}, 84 \mathrm{mg}$ ) were added, stirring for 10 minutes.

At this stage, the water phase was khaki-colored, and the organic phase was dark blue. The organic phase was separated and dried over anhydrous sodium sulfate, followed by the addition of triethylamine $(0.6 \mathrm{mmol}, 85 \mu \mathrm{L})$ to form a mixture. $0.6 \mathrm{mmol}$ of acetyl chloride was added to $1 \mathrm{~mL}$ of dichloromethane and stirred. Then, the triethylamine mixture was slowly added dropwise to prevent the production of a large amount of white smoke, followed by stirring at room

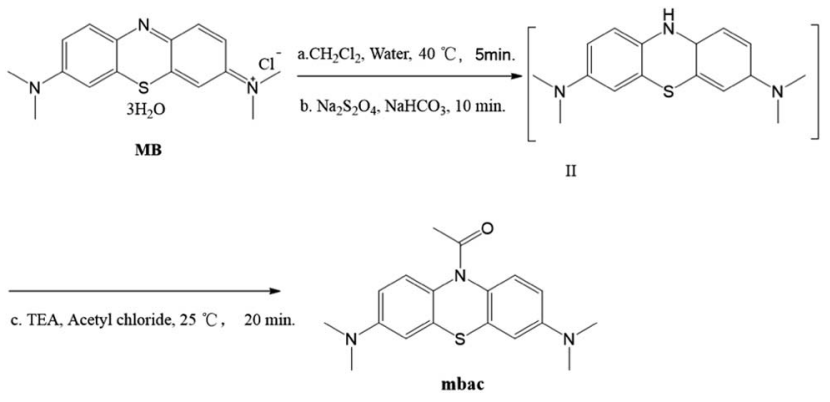

Scheme 2 Synthesis of the probe mbac.

temperature for 20 minutes. The synthesis of a compound with similar structure has been reported. ${ }^{24}$ The reaction process is shown in Scheme 2. The product was purified by column chromatography (alumina, dichloromethane).

Mbac (122 mg, 74.4\%), white powder. ${ }^{1} \mathrm{H}$ NMR (400 MHz, $\left.\mathrm{CDCl}_{3}\right) \delta(\mathrm{ppm}) 2.17\left(\mathrm{~s}, 3 \mathrm{H}, \mathrm{CH}_{3}\right), 2.94\left(\mathrm{~s}, 12 \mathrm{H}, \mathrm{CH}_{3}\right), 6.62(\mathrm{~s}, 2 \mathrm{H}$, $\mathrm{Ar}-\mathrm{H}), 6.71$ (d, $J=2.4 \mathrm{~Hz}, 2 \mathrm{H}, \mathrm{Ar}-\mathrm{H}), 7.26$ (s, 1H, Ar-H), 7.42 (s, $1 \mathrm{H}, \mathrm{Ar}-\mathrm{H}) .{ }^{13} \mathrm{C} \mathrm{NMR}\left(100 \mathrm{MHz}, \mathrm{CDCl}_{3}\right) \delta 170.54,169.28,147.94$, 109.62, 109.83, 39.61, 23.92. HRMS (ESI): $\mathrm{m} / \mathrm{z}$ calcd for $\mathrm{C}_{18} \mathrm{H}_{21} \mathrm{~N}_{3} \mathrm{OS}[\mathrm{M}+\mathrm{H}]^{+}$328.1484, found 328.1452.

General procedure for reactive oxygen detection. The concentration of $\mathrm{ClO}^{-}$was determined by standard titration method before use. The solutions of mbac $(10 \mathrm{mM})$ were prepared in distilled deionized water. In the interference experiments, the probe was mixed in a $1 \mathrm{~mL}$ volume tube with various interfering agents. The solution of the test control group contains $500 \mu \mathrm{M} \mathrm{ClO}^{-}, 10 \mu \mathrm{M}$ probe. All experiments were performed at $25{ }^{\circ} \mathrm{C}$ for 25 minutes. $1 \mathrm{~mL}$ aliquots of the abovementioned mixed solutions were pipetted into $1 \mathrm{~cm}$ cuvettes for spectral measurements. $5 \mathrm{~nm}$ bandpass filters were used for both excitation and emission wavelengths. An excitation wavelength of $660 \mathrm{~nm}$ was used for the acquisition of emission spectra.

Cell culture. LO2 cells and HepG2 cells used in this study were provided by Chinese PLA General Hospital (Beijing, China). HepG2 cells were previously established from human primary HCC. All samples were collected under the guidelines approved by the institutional review board of the Chinese PLA General Hospital. LO2 cells and HepG2 cells were grown on glass-bottom culture dishes (MatTek Co.) in DMEM supplemented with $10 \%(\mathrm{v} / \mathrm{v})$ FBS and $1 \%(\mathrm{v} / \mathrm{v})$ penicillin-streptomycin at $37{ }^{\circ} \mathrm{C}$ in a humidified $5 \% \mathrm{CO}_{2}$ incubator. Before use, the adherent cells were washed three times with FBS free DMEM.

\section{Results and discussion}

\section{Optimization of the experimental conditions}

To check the response of the probe toward $\mathrm{ClO}^{-}$at different time periods, temperature and $\mathrm{pH}$ levels, we conducted several sets of experiments. The fluorescence intensity of the probe toward $\mathrm{ClO}^{-}$has been measured in different conditions. First, we measured the time-dependent emission curve (fluorescence intensity change) of the probe mbac. Fig. 1 shows that under 


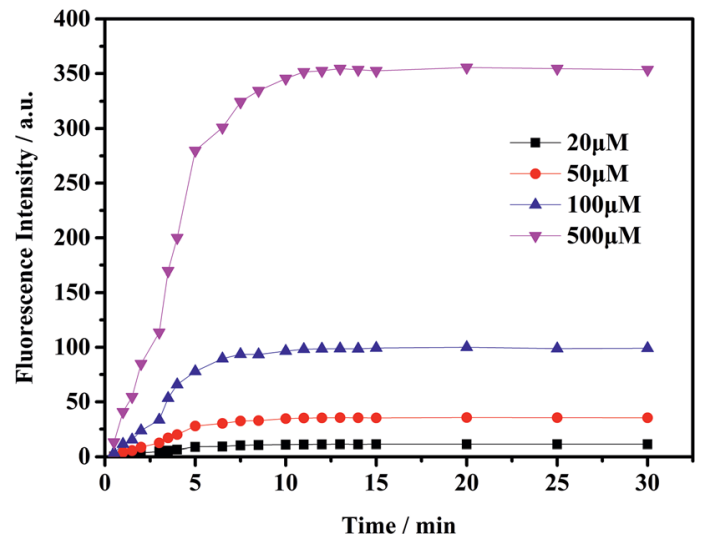

Fig. 1 The time-dependent fluorescence changes $\left(\lambda_{\text {ex }}=660 \mathrm{~nm}\right)$ acquired from a mixture of the probe mbac $(10 \mu \mathrm{M})$ and $\mathrm{ClO}^{-}(20 \mu \mathrm{M}$, $50 \mu \mathrm{M}, 100 \mu \mathrm{M}$ and $500 \mu \mathrm{M})$ in PBS $(\mathrm{pH}=7.4)$ solution at room temperature. Data represent the average of three parallel experiments.

different concentrations of $\mathrm{ClO}^{-}$, the trend of fluorescence intensity is consistent. Fluorescence intensity stopped increasing and stabilized at the highest value after 15 minutes.

The fluorescence intensity of the probe at different $\mathrm{pH}$ levels is shown in Fig. 2. It can be seen that the probe is relatively stable in the $\mathrm{pH}$ range of $3-10$, and the most suitable $\mathrm{pH}$ for measurement is in the range of $5-8$. Therefore, we chose the $\mathrm{pH}$ 7.4 for future experiments.

In addition, in order to investigate the stability of the probe, we measured the fluorescence intensity of the probe at different temperatures. The results show that the probe is relatively stable; the specific data are provided in ESI (Fig S5, Tables S1 and $\mathrm{S} 2 \dagger$ ).

\section{Fluorescence spectral response of mbac}

As shown in Fig. 3, the $\mathrm{ClO}^{-}$concentration is linearly correlated with fluorescence intensity in the range of $0-60 \mu \mathrm{M}$, with a correlation coefficient of 0.9991 and detection limit as low as

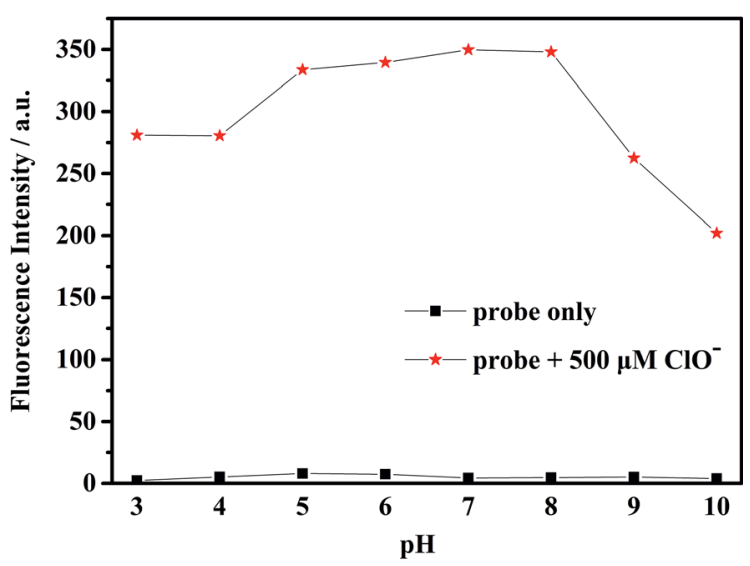

Fig. 2 Fluorescence intensity of the probe mbac $(10 \mu \mathrm{M})$ with and without $\mathrm{ClO}^{-}(500 \mu \mathrm{M})$ in water at different $\mathrm{pH}$ conditions, $\left(\lambda_{\mathrm{ex}}=660\right.$ $\mathrm{nm})$.

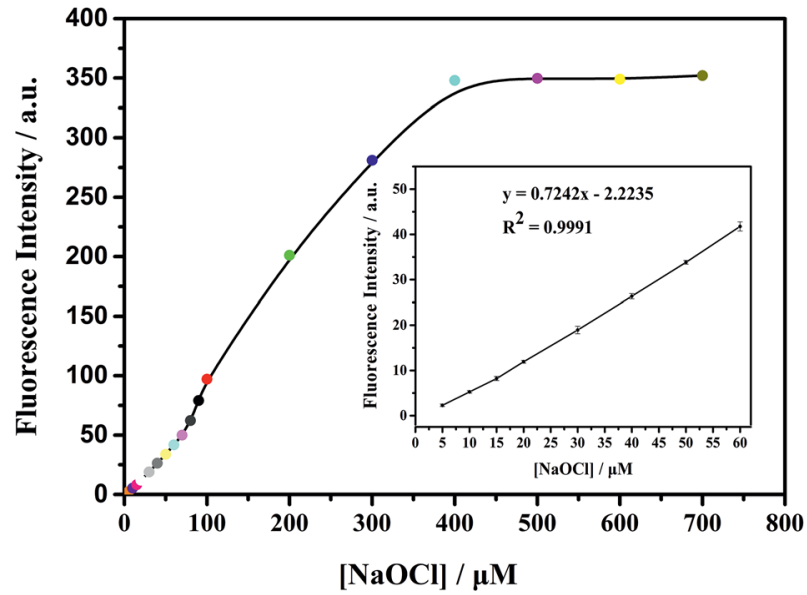

Fig. 3 Fluorescence intensity increases with $\mathrm{ClO}^{-}$concentration $\left(\lambda_{\text {ex }}=660 \mathrm{~nm}\right)$. The system contained the probe mbac $(10 \mu \mathrm{M})$ in PBS $(\mathrm{pH}=7.4)$. Each data point is the average of three parallel experiments. The inset graphic showing the correlation between the fluorescence response of mbac and the concentration of $\mathrm{ClO}^{-}$.

$0.1 \mu \mathrm{M}$. With the increase of fluorescence intensity (about 200 times), it is preliminarily proven that mbac could be used for in vitro detection of $\mathrm{ClO}^{-}$.

In order to further explore the in vitro detection ability of mbac, the UV response of the probe to various concentrations of $\mathrm{ClO}^{-}$was studied. The UV-visible absorption spectra of the probe are shown in Fig. 4.

As shown in Fig. 5, the fluorescent probe mbac has almost no emission in the visible region. After adding $\mathrm{ClO}^{-}$solution, the fluorescence intensity peak appeared near $690 \mathrm{~nm}$ and reached the maximum after incubation at room temperature for $15 \mathrm{~min}$, stabilizing within 30 minutes. As shown in Fig. 4 and 5, the fluorescence intensity at $690 \mathrm{~nm}$ was significantly enhanced with the addition of $\mathrm{ClO}^{-}$. From almost colorless to blue, the process of change is visible to the naked eye (Scheme 1).

The fluorescence excitation and emission wavelengths of mbac both reach the NIR range, which is very favorable for

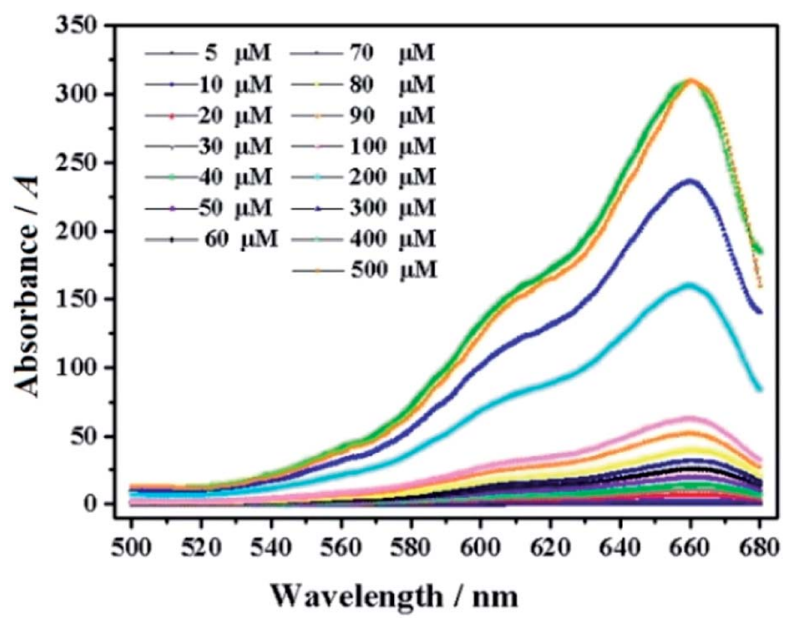

Fig. 4 UV of probe mbac $(10 \mu \mathrm{M})$ upon the addition of $\mathrm{ClO}^{-}(5-500$ $\mu \mathrm{M})$. The system was in PBS $(\mathrm{pH}=7.4)$. 


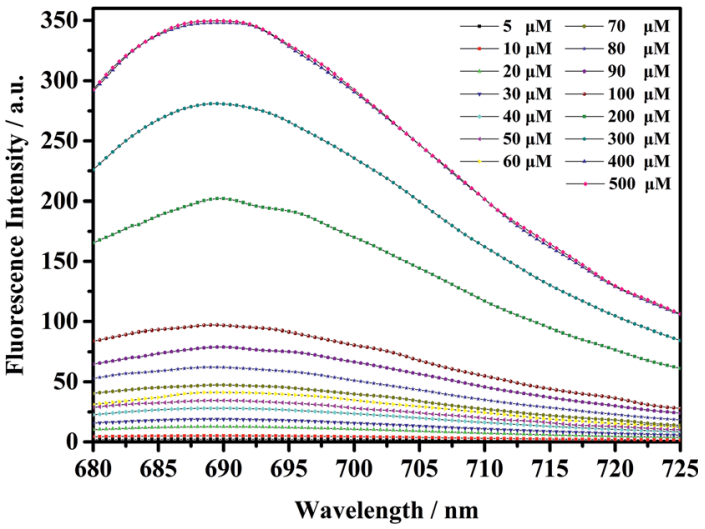

Fig. 5 Fluorescence intensity increase of probe mbac $(10 \mu \mathrm{M})$ upon the addition of $\mathrm{ClO}^{-}(5-500 \mu \mathrm{M}), \lambda_{\mathrm{ex}}=660 \mathrm{~nm}$. The system was PBS $(\mathrm{pH}=7.4)$. The fluorescence intensity was determined at $690 \mathrm{~nm}$.

intracellular imaging. Fluorescence emission can be attributed to the cleavage of the amide bond to release the fluorescent group MB, which is confirmed by HPLC (Fig. S8 $\dagger$ ). The retention time of the probe was 12.87 minutes in HPLC, and for MB was 3.16 minutes. When $\mathrm{ClO}^{-}$was added to mbac, the peaks of mbac disappeared, while the peak of $\mathbf{M B}$ appeared.

\section{Anti-interference}

In order to verify the selectivity of the probe to $\mathrm{ClO}^{-}$, the fluorescence response of mbac was further studied after adding various interfering agents. Fluorescence intensity was measured for probe solutions containing 50 equivalents of various potential interfering ions. Then, 1 equivalent of $\mathrm{ClO}^{-}$ was added, and the intensity was measured again. The results

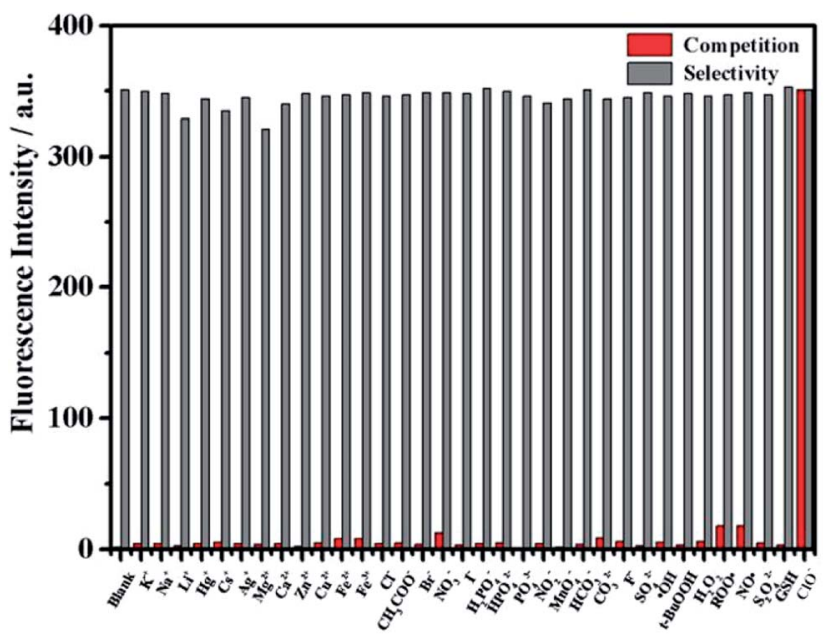

Fig. 6 The fluorescence intensity $\left(\lambda_{\text {ex }}=660 \mathrm{~nm}\right)$ when the probe mbac $(10 \mu \mathrm{M})$ was added to the solutions in PBS $(\mathrm{pH}=7.4)$. The red bars indicate the fluorescence response of mbac to the interfering substance. $\mathrm{K}^{+}, \mathrm{Na}^{+}, \mathrm{Li}^{+}, \mathrm{Hg}^{+}, \mathrm{Cs}^{+}, \mathrm{Ag}^{+}, \mathrm{Mg}^{2+}, \mathrm{Ca}^{2+}, \mathrm{Zn}^{2+}, \mathrm{Cu}^{2+}, \mathrm{Fe}^{2+}$, $\mathrm{Fe}^{3+}, \mathrm{Cl}^{-}, \mathrm{CH}_{3} \mathrm{COO}^{-}, \mathrm{Br}^{-}, \mathrm{NO}_{3}{ }^{-}, \mathrm{I}^{-}, \mathrm{H}_{2} \mathrm{PO}_{4}{ }^{-}, \mathrm{HPO}_{4}{ }^{2-}, \mathrm{PO}_{4}{ }^{3-}, \mathrm{NO}_{2}{ }^{-}$, $\mathrm{MnO}_{4}{ }^{-}, \mathrm{F}^{-}, \mathrm{SO}_{4}{ }^{2-}, \mathrm{HCO}_{3}^{-}, \mathrm{CO}_{3}{ }^{2-}, \mathrm{OH}^{\circ}, t-\mathrm{BuOOH}, \mathrm{H}_{2} \mathrm{O}_{2}, \mathrm{NO}{ }^{\circ}$ ' $\mathrm{S}_{2} \mathrm{O}_{4}{ }^{2-}, \mathrm{GSH}$ and $\mathrm{ClO}^{-}$. Gray bars: after addition of $500 \mu \mathrm{M} \mathrm{ClO}^{-}$. show that the fluorescence intensity of mbac changed obviously only when $\mathrm{ClO}^{-}$was added (see in Fig. 6).

In contrast, other ROS such as ${ }^{\circ} \mathrm{OH}, \mathrm{H}_{2} \mathrm{O}_{2}, t$-BuOOH and $\mathrm{NO}^{\circ}$; other ions such as $\mathrm{K}^{+}, \mathrm{Na}^{+}, \mathrm{Li}^{+}, \mathrm{Hg}^{+}, \mathrm{Cs}^{+}, \mathrm{Ag}^{+}, \mathrm{Mg}^{2+}, \mathrm{Ca}^{2+}, \mathrm{Zn}^{2+}$, $\mathrm{Cu}^{2+}, \mathrm{Fe}^{2+}, \mathrm{Fe}^{3+}, \mathrm{Cl}^{-}, \mathrm{CH}_{3} \mathrm{COO}^{-}, \mathrm{Br}^{-}, \mathrm{NO}_{3}{ }^{-}, \mathrm{I}^{-}, \mathrm{H}_{2} \mathrm{PO}_{4}{ }^{-}, \mathrm{HPO}_{4}{ }^{2-}$, $\mathrm{PO}_{4}{ }^{3-}, \mathrm{NO}_{2}{ }^{-}, \mathrm{MnO}_{4}{ }^{-}, \mathrm{F}^{-}, \mathrm{SO}_{4}{ }^{2-}, \mathrm{HCO}_{3}{ }^{-}$and $\mathrm{CO}_{3}{ }^{2-}$; and other reducing agents such as $\mathrm{S}_{2} \mathrm{O}_{4}{ }^{2-}$ and GSH showed very weak fluorescence enhancement (Fig. 6), even at 50 equivalents. All of the results demonstrate that the probe mbac exhibits high selectivity to $\mathrm{ClO}^{-}$.

\section{Cytotoxicity assay}

The basis of its application is safety, so it is necessary to study the probe's cytotoxicity. We selected LO2 cells (human normal liver cell) to measure the cytotoxicity of this probe. No apparent cytotoxicity was observed after LO2 cells were treated with mbac.

The methyl thiazolyl tetrazolium (MTT) assay was used to measure the cytotoxicity of mbac in LO2 cells. LO2 cells were seeded into a 96-well cell-culture plate. Cells were dosed with mbac at final concentrations ranging from $6.25 \mu \mathrm{M}$ to $100 \mu \mathrm{M}$ in each well of the plates. The cell survival was determined by measuring the absorbance at $490 \mathrm{~nm}$ by using a microplate reader. A calibration curve was prepared using SPSS to determine the IC50 of probe-mbac. Cytotoxicity at IC50 is the concentration of compound at which the optical density of

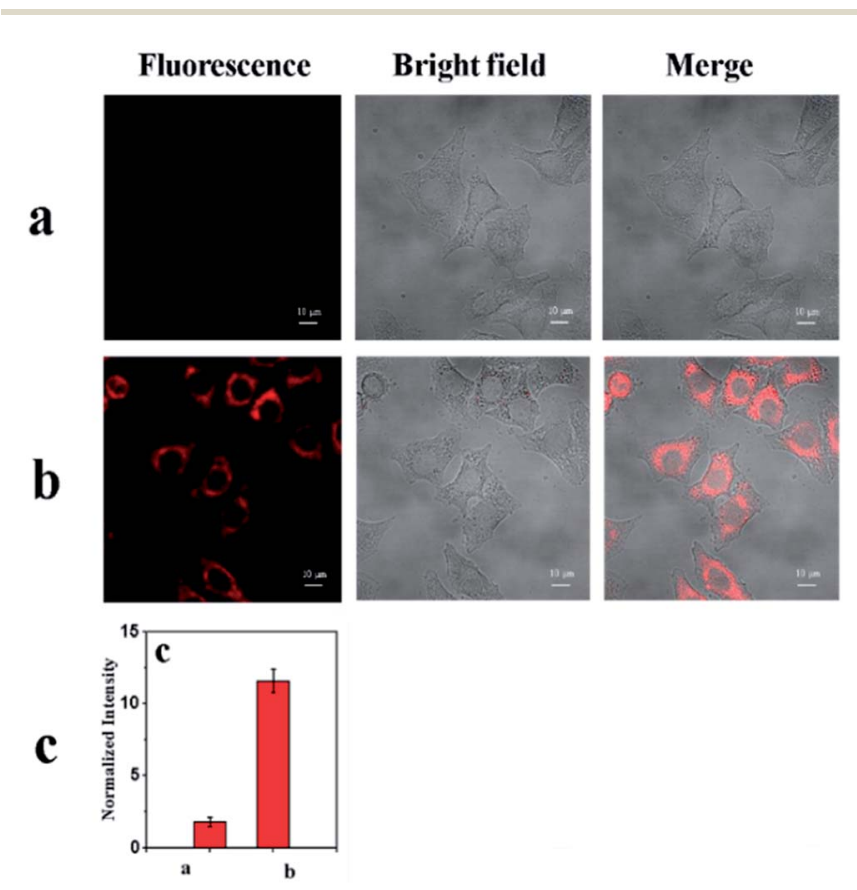

Fig. 7 Fluorescence images of HepG2 cells. Left: fluorescence image; middle: bright-field image; right: merged image. (a) Cells were stained with $10 \mu \mathrm{M} \mathrm{mbac}$ (negative control) and incubated for $30 \mathrm{~min}$ at $20^{\circ} \mathrm{C}$. (b) The HepG2 cells were simultaneously incubated with $10 \mu \mathrm{M} \mathrm{ClO}^{-}$ and $10 \mu \mathrm{M}$ probe for $30 \mathrm{~min}$ at $20^{\circ} \mathrm{C}$. (c) Relative fluorescence intensities of (a) and (b). The images were acquired using a confocal microscope with $633 \mathrm{~nm}$ excitation and $660-750 \mathrm{~nm}$ collection. Scale bar: $10 \mu \mathrm{m}$. 
Table 1 Application of probe mbac $(10 \mu \mathrm{M})$ in water samples (Beijing Chaoyang), compared with $\mathrm{ClO}^{-}$. Measured at $\lambda_{\text {ex }}=660 \mathrm{~nm}$ and measured at $690 \mathrm{~nm}$

\begin{tabular}{lcl}
\hline Samples & $\begin{array}{l}\text { Average fluorescence } \\
\text { intensity/a.u. }\end{array}$ & RSD \\
\hline Tap water & 8.305 & 0.084889 \\
Boiled water & 4.829 & 0.14549 \\
ClO $^{-}$ & 348.705 & 0.000875 \\
Blank & 2.185 & 0.009153
\end{tabular}

treated cells ( $48 \mathrm{~h}$ ) is reduced by $50 \%$ with respect to untreated cells using the MTT assay. The cell viability at various mbac doses was $95.2 \%, 100.5 \%, 106.5 \%, 102.1 \%$ and $104.8 \%$. The results are shown in Fig. $\mathrm{S} 9 ; \dagger$ mbac exhibits a relatively low cytotoxicity in LO2 cells after exposure to up to $100 \mu \mathrm{M}$ mbac for $48 \mathrm{~h}$.

\section{Applications of mbac}

As shown in Fig. 7a, the probe mbac showed little fluorescence signal, consistent with fluorescence spectroscopy using HepG2 cells (human hepatocellular cancer cells).

On the other hand, a distinct emission response could be observed (Fig. 7b) after incubation with $\mathrm{ClO}^{-}$for $30 \mathrm{~min}$. The results show that the cell permeability of the probe mbac is good. Thus, mbac can be used to estimate the concentration of intracellular $\mathrm{ClO}^{-}$.

MBAC was also expected to be cell-membrane permeable, per the calculated $\log P$ of 3.82 obtained with the ALOGPS 2.1 programme. ${ }^{25}$ The predicted value of $\log P$ is within the range indicating good capacity to cross the plasma membrane. ${ }^{26}$

Under physiological conditions, $\mathrm{ClO}^{-}$is highly reactive and short-lived; the average level of $\mathrm{ClO}^{-}$generation from neutrophils is $0.47 \mathrm{nmol} \mathrm{min}{ }^{-1}$ per 106 cells. $^{27}$ Thus, when only the probe is added, the fluorescence in the cell is almost invisible. Furthermore, we hope to use this probe to detect $\mathrm{ClO}^{-}$in living samples. The results are shown in Table 1 ; the fluorescence intensity of several samples is less than 10 a.u., tested in tap water andboiled water (Chaoyang, Beijing).

Furthermore, we found that boiled water contained less $\mathrm{ClO}^{-}$than tap water. The results show that mbac is a common tool that can be successfully applied to the detection of $\mathrm{ClO}^{-}$ species in environmental samples.

\section{Conclusions}

In conclusion, we have developed a fluorescent probe, mbac, whose absorption and emission wavelengths are both near infrared, with fast response and long response times, low cost and high specificity in the detection of $\mathrm{ClO}^{-}$. It is worth mentioning that the fluorescence intensity of the probe is enhanced by nearly 200 times, and the detection limit is $0.1 \mu \mathrm{M}$. The decomposition product has high safety as a clinical agent. In addition, we successfully measured the $\mathrm{ClO}^{-}$concentration in different water samples by using mbac. The results of confocal laser microscopy demonstrate that the above theory can be applied at the cellular level. In summary, the probe mbac has a good prospect in measuring $\mathrm{ClO}^{-}$in the fields of environment and biology.

\section{Conflicts of interest}

There are no conflicts of interest to declare.

\section{Acknowledgements}

The authors would like to acknowledge financial support from Beijing Key Laboratory of Environmental and Viral Oncology, Key Laboratory of Bioorganic Phosphorus Chemistry and Chemical Biology (Ministry of Education) and Beijing Key Laboratory for Green Catalysis and Separation.

\section{Notes and references}

1 W. Shu, L. Yan, Z. Wang, J. Liu, S. Zhang, C. Liu and B. Zhu, Sens. Actuators, B, 2015, 221, 1130-1136.

2 X. Jin, Y. Jia, W. Chen, C. Ping and Z. Yang, Sens. Actuators, B, 2016, 232, 300-305.

3 Y. Zhao, H. Li, Y. Xue, Y. Ren and T. Han, Sens. Actuators, B, 2017, 241, 335-341.

4 J. Park, H. Kim, Y. Choi and Y. Kim, Analyst, 2013, 138, 33683371.

5 N. Zhao, Y. Wu, R. Wang, L. Shi and Z. Chen, Analyst, 2011, 138, 2277-2282.

6 C. C. Winterbourn, M. B. Hampton, J. H. Livesey and A. J. Kettle, J. Biol. Chem., 2006, 281, 39860-39869.

7 G. Li, D. Ji, S. Zhang, J. Li, C. Li and R. Qiao, Sens. Actuators, $B, 2017,252,127-133$.

8 H. F. Tang, Y. H. Yi, X. S. Yao, Q. Z. Xu, S. Y. Zhang and H. W. Lin, J. Asian Nat. Prod. Res., 2002, 4, 95-101.

9 S. Khatib, R. Musa and J. Vaya, Bioorg. Med. Chem., 2007, 15, 3661-3666.

10 K. Xiong, F. Huo, C. Yin, J. Chao, Y. Zhang and M. Xu, Sens. Actuators, B, 2015, 221, 1508-1514.

11 Y. R. Zhang, Y. Liu, X. Feng and B. X. Zhao, Sens. Actuators, B, 2017, 240, 18-36.

12 Z. Q. Hu, J. H. Zhu, Y. Y. Gu, W. Z. Hu, M. Li and Y. Jiang, Microchim. Acta, 2014, 181, 1401-1406.

13 S. Y. Yu, C. Y. Hsu, W. C. Chen, L. F. Wei and S. P. Wu, Sens. Actuators, B, 2014, 196, 203-207.

14 Y. Koide, Y. Urano, K. Hanaoka, T. Terai and T. Nagano, J. Am. Chem. Soc., 2011, 133, 5680-5682.

15 M. Wagner, E. R. Suarez, T. R. Theodoro, C. D. MachadoFilho, M. F. Gama, J. P. Tardivo, F. M. Paschoal and S. M. Pinhal, Clin. Exp. Dermatol., 2012, 37, 527-533.

16 H. Y. Tan, J. G. Liu, L. F. Zhou, Y. K. Li, J. W. Yan and L. Zhang, RSC Adv., 2017, 7, 6583-6586.

17 K. G. Chernov, T. A. Redchuk, E. S. Omelina and V. V. Verkhusha, Chem. Rev., 2017, 117, 6423-6446.

18 S. V. Eliseeva, I. P. Golovach, V. S. Liasotskyi, V. P. Antonovich, S. Petoud and S. B. Meshkova, J. Lumin., 2016, 171, 191-197. 
19 A. Haque, M. S. Faizi, J. A. Rather and M. S. Khan, Bioorg. Med. Chem. Lett., 2017, 25, 2017-2034.

20 K. Wang, T. Leng, Y. Liu, C. Wang, P. Shi, Y. Shen and W. H. Zhu, Sens. Actuators, B, 2017, 248, 338-345.

21 J. Xu, H. Yuan, C. Qin, L. Zeng and G. M. Bao, RSC Adv., 2016, 6, 107525-107532.

22 S. Ding, Q. Zhang, S. Xue and G. Feng, Analyst, 2015, 140, 4687-4693.

23 Z. P. Li, Y. F. Wang, X. Zhang, C. Zeng, L. Hu and X. J. Liang, Sens. Actuators, B, 2017, 242, 189-194.
24 V. B. Sokolov, A. Y. Aksinenko, T. A. Epishina, T. V. Goreva, V. V. Grigoriev, A. V. Gabrel Yan and S. O. Bachurin, Russ. Chem. Bull., 2015, 64, 718-722.

25 I. V. Tetko and V. Y. Tanchuk, J. Chem. Inf. Comput. Sci., 2002, 42, 1136-1145.

26 M. Kamiya, D. Asanuma, E. Kuranaga, A. Takeishi, M. Sakabe, M. Miura., T. Nagano and Y. Urano, J. Am. Chem. Soc., 2011, 133, 12960-12963.

27 H. Zhu, J. Fan, J. Wang, H. Mu and X. Peng, J. Am. Chem. Soc., 2014, 136, 12820-12823. 